\title{
A review of contemporary trends in Higher Education assessment
}

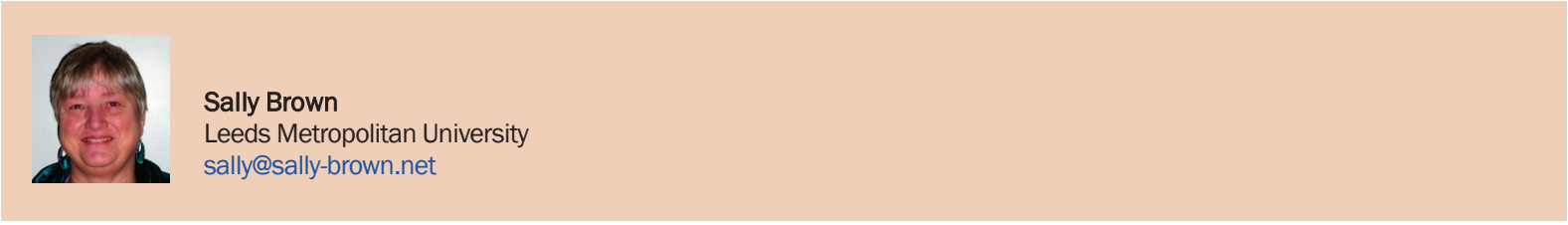

|Presented: 26/09/2014 | Accepted: 20/02/2015 |Published: 22/06/2015

\section{Resumen}

La evaluación tiene una gran importancia, y contribuye significativamente al aprendizaje de los estudiantes, sobre todo cuando está diseñada para ser adecuada a su propósito, cuando es auténtica y está centrada en la integración de la evaluación con el aprendizaje (lo que comúnmente se denomina evaluación para el aprendizaje). Sobre la base de buenas prácticas internacionales, este artículo propone doce tendencias actuales de evaluación y diez principios para asegurar buenas prácticas, al tiempo que se reconoce que este es un campo en constante evolución, que continuará siendo un reto para los académicos que se impliquen en la evaluación.

Palabras clave: evaluación, evaluación adecuada a su propósito, tecnologías para la evaluación, diversidad internacional de evaluación, evaluación inclusiva

\section{Resum}

L'avaluació en té un gran importància, i contribueix significativament a l'aprenentatge dels estudiants, especialment quan està dissenyada per a ser adequada al seu propòsit, quan és autèntica i està centrada en la integració de l'avaluació amb l'aprenentatge (el que comunament és denomina avaluació per l'aprenentatge). Sobre la base de de bones pràctiques internacionals, aquest article proposa dotze tendències actuals d'avaluació i deu principis per assolir bones pràctiques, al temps que reconeix que aquest és un camp en constant evolució, que continuarà sent un repte per als acadèmics que s'impliquen en l'avaluació.

Paraules clau: avaluació, avaluació adequada al seu propòsit, tecnologies per a l'avaluació, diversitat internacional d'avaluació, avaluació inclusiva

\section{Abstract}

Assessment is of high importance and contributes significantly to student learning, especially when it is designed to be fit-for-purpose, authentic and focused on integrating assessment with learning (commonly termed 'assessment for learning'). Drawing on international good practice, this article proposes twelve current assessment trends and ten principles for assuring good practice, while recognising that this is an ever changing field which will continue to challenge academics involved in assessment.

Key words: assessment, fit-for-purpose assessment, technologies for assessment, international diversity in assessment, inclusive assessment 


\section{Introduction}

If we want better graduates who are better prepared to succeed in the twenty-first century in a highly competitive global environment, we need to assess our students better. Assessment has such a crucial role to play not only in evaluating what students have learned and what they can do, but also in motivating them to learn and ensuring that they direct their energies appropriately (Boud 2007).

"Research and experience tell us very forcefully about the importance of assessment in higher education. It shapes the experience of students and influences their behaviour more than the teaching they receive". (Bloxham and Boyd 2007, 3.)

Poor assessment, conversely leads to poor academic conduct, with an excessive focus on working to the test rather than deeply engaging with the subject, and a higher tendency to plagiarise, cut corners and behave strategically (Kneale, 1997). This article aims to review strategically what are the key trends in contemporary higher education, and to propose some principles for assuring good assessment practice.

\section{Twelve current assessment trends}

\section{Assessment for learning}

Perhaps the strongest perceivable trend is to aim to ensure that assessment is fully integrated with student learning. Higher education practitioners recognise the importance of assessment as a driver for learning and a means by which it occurs rather than just a method of judging student performance. Researchers in the UK and elsewhere (Bloxham and Boyd 2007, Boud and Associates 2010, Gibbs and Simpson 2005, Ibarra-Sáiz and Rodríguez-Gómez 2010, Sambell, McDowell and Montgomery 2012, Brown and Race 2012) all propose that assessment needs to change, to become more central to the learning process, rather than a subsequent add-on, and to fully engage students if it is to be valuable in its own right. Assessment for Learning particularly as defined by the team who led the Assessment for Learning (A4L) Centre for Excellence in Teaching and Learning at the University of Northumbria ${ }^{1}$ implies that A4L:

\footnotetext{
- "Emphasises authenticity and complexity in the content and methods of assessment rather than reproduction of knowledge and reductive measurement.

- Uses high-stakes summative assessment rigorously but sparingly rather than as the main driver for learning. - Offers students extensive opportunities to engage in the kinds of tasks that develop and demonstrate their learning, thus building their confidence and capabilities before they are summatively assessed.

- Is rich in feedback derived from formal mechanisms e.g. tutor comments on assignments, student self-review logs. - Is rich in informal feedback e.g. peer review of draft writing, collaborative project work, which provides students with a continuous flow of feedback on 'how they are doing'.

- Develops students' abilities to direct their own learning, evaluate their own progress and attainments and support the learning of others." (Brown 2015, 107)
}

Assessment for learning implies significant and meaningful use of formative assessment, while using summative assessment sparingly but rigorously (Gibbs 2010). Formative assessment has specific purposes since it:

"Forms and informs [student work], and is primarily concerned with giving feedback that is aimed at prompting improvement in student work. It is often continuous and usually involves plenty of words. Summative assessment is concerned with summing up and making evaluative judgments, is often end-point and involves numbers and grades rather than words" (Brown 2015, 128).

A significant trend in current assessment is to rebalance the amount of summative and formative assessment, so as to ensuring that the feedback reaches students promptly and at a time when they can learn from the experience to inform future tasks, and is developmental.

\section{Strategic assessment design}

Good assessment is not a matter of good luck: assessment that engages students and fosters learning is designed strategically to fit the occasion, the students, the context, the subject and the level. Assessment needs to be constructively aligned with the curriculum (Biggs and Tang 2011), so that student learning of the specified outcomes in the published documentation associated with a programme is fully represented in the assignments that students undertake. Those who adopt a fit-for-purpose assessment approach seek to offer assignments that are clear about the purpose of a particular task, use appropriate methods and approaches, are assessed by the right people at the right time to support student learning (Brown 2015). Students need confidence that they will be assessed fairly and justly and they need to be really clear about what is required of them and what standards of work are expected. Assessors need to be confident that their workload is manageable and they are well-placed to make judgements about the quality of work. Institutions need to be able to justify the standards embodied in the qualifications they award, and employers need reassurance that graduates are able to fulfil employment requirements. This implies a highly professional and nuanced approach to assessment design that is purposeful and focuses more on enhancement and less on monitoring (Quesada-Serra et al. 2014). It is also important that curriculum designers avoid assessment design being undertaken at a module-only level: a key current trend in assessment is to consider assessment across a whole programme to ensure a coherent and integrated assessment experience for students (McDowell 2012).

\section{Assessment literacy}

Students globally may have widely divergent experiences and expectations of what university-level assessment requires. Those with parents or other family members who have been in higher education may have a better understanding of what terms like criteria and weighting mean than students with less social and cultural capital. By building assessment literacy development activities into, for example, the crucial first six weeks of the first semester of the first year of university study, academics can enhance student achievement and retention. (Yorke 1999). Sambell (2013) 
makes a strong case for enabling students to have a sophisticated and articulated understanding of what goes on inside the black hole that assessment is sometimes perceived to be. Price et al. (2012), further argue for building into the curriculum a range of activities that require students to engage fully with the practicalities and nuances of assessment practice as a means of engendering engagement and maximising students' chances of success. This is particularly important in contexts where students from different nations study away from home, because learned behaviours that worked in one context may not be useful in others, for example, the extent to which memorisation and reproduction in assignments is valued.

\section{More (or less?) time on assessment activities}

There are competing and potentially mutually exclusive tensions concerning the amount of time and resource to spend on assessment. There is, for example, evidence of expectations by students, particularly in countries where they pay substantial higher education fees that they should receive detailed formative and developmental feedback that is supportive, personalised and helps them integrate their learning (Nicol and Mcfarlane Dick 2006). A number without words of advice is rarely considered sufficient in these cases.

At the same time there are often directives by university managers that academics need to do more with less, that is, spend less time on assessment. For some this means making best use of available technologies to reduce the drudgery of repetitive marking and to similarly cut down on the time academics and administrators spend on managing the assessment process, but other less scrupulous managers regard assessment as a time-waster for lecturers who could be doing other academic work, particularly research.

The tendency in coming years will be for assessors to make more strategic decisions about how they use their time on assessment-related activities: avoiding drudgery as far as possible but making sure that all time accorded will be spent prudently to give maximum pay-off in terms of learning.

\section{Technologies to enhance learning}

There have been significant advances in the potential for technologies to support assessment in the last three decades (Beetham 2013, JISC 2007, JISC 2010). Computer-based assessment (CBA) nowadays goes well beyond simple multiple-choice questions with a single correct answer and instead requires significant cooperative design and testing, using expertise in question design, subject knowledge and the requisite technologies to ensure effective assessment. CBA can encompass a wide range of simulation activities, non-text tasks and case study analysis, as well as more traditional multi-choice questions. When predicting the future of assessment, few commentators would demur from the expectation that technologies will be increasingly used to support all aspects of assessment.

At a wider level, implementing a means of electronic management of assessment (EMA) is crucial nowadays. EMA is 'the way that technology can be used to support the management of the whole assessment and feedback lifecycle, including electronic submission of assignments, marking, feedback and the return of marks and feedback' (Ferrell 2014, 4). Such systems, including those from vendors including Blackboard, Moodle, Turnitin, Livetext and so on, can increase efficiency but need a systematic and institution-wide approach if they are to have high impact. While administrators and students are often highly in favour of EMAs, academics are sometimes reluctant to cede control of some aspects of the quality control of assessment and there is often a marked reluctance regarding online marking (Farrell 2014, 30). Without doubt, the days are numbered for the practice of hand marking paper scripts with a pen, since this approach is so problematic for students who can't read poor handwriting nor decode cryptic comments and is so time-consuming and repetitive for academics.

\section{Assuring the quality of assessment}

There is a growing interest at institutional, national and international level in assuring the quality of assessment, with detailed guidance on assessment processes and good practice provided. Such advice is frequently provided by Professional, Subject and Regulatory Bodies (like Law Societies and Engineering Councils), governmental bodies (including the Quality Assurance Agency and the Higher Education Academy in the UK, Australian Learning and Teaching Council, and the Higher Education Authority in Ireland,) as well as international groups European initiatives (McAleese 2013). Assessment is rarely seen nowadays as a private matter to be left to the discretion of the individual assessor, nor indeed to individual institution's (sometimes arcane) regulatory frameworks.

There are often advanced expectations that staff new to assessment will be trained and inducted into how to mark fairly, validly and consistently, and that experienced markers will engage in moderation activities to ensure inter- and intra-marker reliability, so several markers working on a shared set of scripts, and individual markers working their way through many scripts will ensure that each student is judged justly against agreed criteria (for example, in the UK QAA, 2013, Indicator 10, p. 14 and HEA, 2012). Many nations in Europe, Australasia and elsewhere now argue for training and CPD for university teachers to be undertaken to improve both teaching and assessment, (e.g. Ibarra-Sáiz and Rodríguez-Gómez 2010). Recommendation 4 of the Report to the European Commission on improving the quality of teaching and learning in Europe's higher education institutions (McAleese 2013, p. 15) argues that:

"All staff teaching in Higher Education institutions in 2020 should have received certified pedagogical training. Continuous professional development as teachers should be a requirement of teachers in the higher education sector".

This trend toward professionalisation of all aspects of university teachers' work, especially assessment, is likely to be an ongoing one, not just in Europe but across the globe.

7. More challenges by students of assessment judgments

Formerly student complaints about assessment tended to be about due process not being followed but nowadays increasingly students (and their parents in fee-paying countries) are more likely to challenge the basis on which judgments are made. This has led in some cases to more risk-averse behaviour on the part of assessors, who may prefer to use assessment types which rely less heavily on judgment of performance and instead, for example, use multiple choice tests which are seemingly more objective. However, even though such methods are on the surface less subject to bias (with any subjectivity hidden within the design of the 
questions, for example) they may be less effective at judging higher level learning outcomes than more fit-for-purpose assignments. Assessors and those designing assessment are likely in coming years to undertake risk assessments associated with changing assessment practices, although they would also be wise to consider the risks of not changing old practices in a time when student expectations are high.

\section{Assessment Agency}

Currently the vast majority of assessment is undertaken by academics and their proxies including senior students and graduate teaching assistants. Studies in Australia, (Sadler 2010, Boud 1995), the UK, (Falchikov 2004, Race 2001), Spain, (Rodríguez-Gómez, Ibarra-Sáiz and Jiménez 2013) and elsewhere argue for the benefits of involving students in their own and each other's assessment as an important means of helping them gain a deeper understanding of what assessors are seeking in assessed work. The benefits of self and peer assessment are demonstrably so valuable that it is worth overcoming the recognised reluctance of some students to put their grades in the hands of fellow students. To work well, self and peer assessment rely not on snap judgments based on feelings, but on careful calibration of evidence of achievement against explicit criteria. Self and peer assessment should never be undertaken without clear briefing, sensitive training, risk-free rehearsal and dialogic opportunities.

The UK National Union of Students assessment and feedback benchmarking tool ${ }^{2}$ proposes that to be effective, assessment criteria should be:

"clear, easily accessible and linked to learning outcomes. Students fully understand and are supported to use them. They are designed in partnership with students to ensure accessibility". (NUS, 2014).

Using such assessment criteria as part of an ongoing iterative and incrementally developed process can enable students to assess themselves and each other fairly and validly. Where this is the case, such assessment can be used summatively, as well as the more common formative use.

Employers, placement supervisors, practice mentors, clients and others are all increasingly being involved in assessment of students, and again briefing and moderation are essential features of broadening the range of people undertaking assessment, together with as before a very clear focus on marking according to evidence presented against the assessment criteria.

\section{Authentic assessment}

This implies that the tasks students are required to undertake should be closely linked with published learning outcomes, and should be realistic in format. For example, if assessors want to know whether students understand the interpersonal issues involved in effectively working as a member of a team, it is much more authentic to give them a group task to undertake and reviewing their individual and collective performance of it than it is to ask them simply to write an exam answer about teamwork. Peer assessment of colleagues working in their own groups is a valuable way to evaluate behaviours that are not normally visible to the tutor. Employers particularly value graduates who can demonstrate skills and capabilities developed in realistic assessment scenarios.

A case study of good practice in using authentic assessment approaches by Lopez-Pastor (in Brown 2015, 130-2), describes using incremental and ongoing feedback assessment with early years student teachers in Spain. In addition to evaluating students' competences, the programme requires students to demonstrate their reflection on practice and to demonstrate development over their period of study. It is popular with the teachers who supervise the students' practice because it is perceived as rigorous and supportive, and also because they are able immediately to resolve any problems that students are experiencing before the end of the teaching practice.

In coming years, there is likely to be continuing pressure from students, employers and other stakeholders for assessment to be meaningful and to relate to the kinds of realworld contexts students will experience on graduation.

10. Growing concerns about plagiarism and cheating

These and other forms of poor academic conduct have led to significant efforts both to design out opportunities for students to cheat (e.g. Newstead 1996, Carroll 2002).

In effect academics can come at this from four directions:

- using technologies like Turnitin or Safeassign to catch students who submit part or whole assignments that are not their own, using frequently cut and pasted from the internet, through text matching systems against extant resources;

- designing assignments and systems that reduce opportunities for plagiarism, like in-class activities, scrupulously invigilated exams and incrementally reviewed tasks;

- having well-publicised and effective systems to catch and punish those who cheat;

- developing a culture of honour where students themselves regard such behaviour as unacceptable. (after McDowell and Brown 2001).

Of these four, the ones most likely to succeed are designing out opportunities to plagiarise and using technologies, though it is much more difficult to prevent or catch out students who commission bespoke assignments through socalled 'essay mills' where unscrupulous postgraduates and even academics write assignments to order for hard cash.

\section{International diversity in assessment practice}

Advances in global higher education practices and staff/student mobility, with a wider recognition that there are multiple approaches to assessment in different nations globally, with the potential for mutual learning, and no monopoly by a single nation or group of nations on correct ways of assessing, are discussed in Brown and Joughin (2007). Issues of divergence are likely to include:

- The amount of one-to-one support students can expect from their tutors prior to submission;

- The amount and quality of feedback students are likely to receive after the assignments have been 
marked, and the extent to which students are expected to respond to it;

- The extent to which marks, once awarded, are negotiable;

- How grading systems work: for example a 'B' in the UK system is a reasonably good mark but in the US system it would be considered a poor contributor to the Grade Point Average;

- Approaches to referencing vary: in some nations these are rather open whereas elsewhere, for example in the UK, there are very rigorous expectations about acknowledgment of sources and citing references correctly;

- The types of assessment methods in use which are highly variable: in some nations multiple choice questions prevail and elsewhere there is a focus on open text answers. Time constrained unseen exams predominate in some countries with others using more oral assessment (as in Scandinavia and Northern Europe) and others use more continuous assessment in the form of essays and reports;

- How much external scrutiny there is of assessment: in some nations including Ireland, New Zealand and the UK, national quality bodies take a close interest in how quality and standards are assured. Elsewhere, systems of external examiners and moderators are not used.

- The extent that technology is used for assessment: in nations including the US and Singapore computer-based assessment is much more widely used than is the case in a number of southern European nations.

Implications for practice of the global diversity of assessment in higher education are a requirement for induction for staff and students about the different assessment practices they are likely to encounter when working and studying outside their home nations.

\section{A commitment to inclusive assessment}

Assessment judgments should be based on evidence of the achievement of stated criteria, notwithstanding the race, ethnicity, gender, cultural or social background or physical health or status of the student being assessed and for this reason many nations have adopted strong anti-discriminatory legislation to ensure the inclusivity of assessment in all levels of education, for example the Special Educational Needs and Disabilities Act (SENDA) in the UK. SENDA requires, for example, that reasonable adjustments be made for students with disabilities, such as the provision of software to enable visually-impaired students to hear rather than see examination papers, or for students with chronic fatigue syndrome to undertake elements of a prescribed task incrementally rather than at one sitting.

Sensitive higher education institutions don't timetable required assessed tasks on Sabbaths, late in the day during fasting times over Ramadan or on Catholic feast days. They don't include among criteria for presentations making eye contact with assessors for students from cultures (for example among Maori people in New Zealand or some Asian nations) where doing so is deemed inappropriate or improper. Organising and managing inclusive assessment practices is time consuming and complex, but less so than trying to sort out matters at the time of an assessment or dealing with justifiable complaints afterwards.

Whereas formerly students were largely expected to sink or swim, with little account being taken of special circum- stances or needs, nowadays students and their parents are likely to be intolerant of assessment practices which are seen as being unjust and unreasonable.

\section{Conclusions}

Reviewing trends is not a foolproof process, and it is impossible to anticipate all that is likely to happen in coming years. However, having reviewed the state-of-the-art assessment context, here are proposed some suggestions that are likely to remain current in the coming years.

\section{Ten principles for assuring good assessment practice}

1. Every decision taken, whether it is on what is to be assessed, when it is to be assessed, by whom, and how, needs to be taken consciously, with a clear imperative in mind to enhance student learning. Established patterns may have to be challenged, and this may be disruptive, but this is unavoidable if assessment is to satisfy all the multiple requirements laid upon it.

2. A strong focus on prompt and developmental formative feedback is likely to have high impact on effective student learning, so it needs to be foregrounded. Both curriculum delivery and current assessment practices may need to change in order to make space and time for the centrality of formative feedback which can not just provide comments and corrections on students' work to date, but can influence students' future work: this is commonly described as feed-forward.

3. Innovations in assessment should be undertaken prudently and with due regard for the extensive literature in the field. Scholarly approaches to change are likely to be better received by students, academic colleagues and quality assurance staff than impromptu implementation of bright ideas.

4. Student perspectives on assessment design should be sought early in the curriculum creation process, since as potential end-users, they are likely to have helpful comments on how to ensure assignments work well.

5. While assessment will always exist in a context of power imbalance between the marker and the marked, it is always helpful to foster the dialogic elements of assessment to maximise its impact on learning.

6. Assessment needs to be fair and seen to be fair for students to take it seriously. For this reason, plagiarism needs to be tackled rather than glossed over, and students need to be able to perceive that they are treated with equity and justly (Flint and Johnson 2011).

7. Hygiene factors associated with assessment must be carefully assured. Assignment submission dates and exam dates must be made available early and adhered to. Criteria need to be explicit and accessible and assignment briefings need to be made available in a durable format so that, for example, students unavoidably absent from briefings should be able to access the video or text version on the web. Security of tests and exams should be safeguarded. Exam rooms should provide facilities sufficient to ensure students can undertake tests in comfort, and exams should be impartially invigilated. 8. Where possible assessment tasks should be engaging and even potentially enjoyable: students should feel satisfaction in completing them and academics should be able to recognise the learning that has taken place under their care. 
9. Designing manageable, effective and incentivising assignments should not be a task for a single individual: avoidance of poor assessment design requires as a minimum a small team to discuss, confer and check draft assignments and to monitor their effectiveness in practice. This is particularly true of e-Assessment. The most effective universities have systems in place to ensure the reliability and validity of assessment, and to ensure they align with national as well as Professional, Regulatory and Subject body requirements.

10. Assessment must always be undertaken respectfully and feedback should focus on the submitted work rather than the individual's personality or previous track record. Good assessment helps students enhance their self-efficacy while poor assessment can undermine selfconfidence and result in higher rates of student failure and under-achievement.

If we achieve all of these we can be confident that assessment is fit-for-purpose and fully integrated with learning: that is not ubiquitously the case in universities nowadays but it is a worthy aspiration towards which to aim.

\section{References}

Beetham, Helen (2013). Designing for learning in an uncertain future. In Beetham, Helen and Sharpe, Rhona (Eds.) Rethinking pedagogy for a digital age $\left(2^{\text {nd }}\right.$ edition), London: Routledge.

Biggs, John B. and Tang, Catherine (2011). Teaching for Quality Learning at University: $4^{\text {th }}$ edition, Maidenhead: SRHE/Open University Press.

Bloxham, Sue and Boyd, Pete (2007). Developing Effective Assessment In Higher Education: A Practical Guide. McGraw-Hill International.

Boud, David (1995). Enhancing learning through self-assessment, Abingdon: Routledge.

Boud, David (2007). Reframing assessment as if learning were important. Rethinking assessment in higher education: Learning for the longer term, 14-25.

Boud, David (2010). Assessment 2020: Seven propositions for assessment reform in higher education, Sydney: Australian Learning and Teaching Council.

Brown, Sally and Joughin, Gordon (2007). Assessing international students: Helping clarify puzzling processes, in Internationalising Higher education (Eds. Elspeth Jones \& Sally Brown), London: Routledge.

Brown, Sally (2015). Learning, teaching and assessment in higher education: global perspectives, London: Palgrave-MacMillan.

Brown, Sally and Race, Phil (2012). Using effective assessment to promote learning, in Hunt, Lynne and Chalmers, Denise University Teaching in Focus: a learning-centred approach, Victoria, Australia: Acer Press, and Abingdon: Routledge.

Carroll, Jude (2002). A handbook for deterring plagiarism in higher education, Oxford: Oxford Centre for Staff and Learning Development

Falchikov, Nancy (2004). Improving Assessment through Student Involvement: Practical Solutions for Aiding Learning in Higher and Further Education, Abingdon: Routledge

Ferrell, Gill (2014). Electronic management of assessment (EMA); a landscape review, Bristol: JISC
http://repository.jisc.ac.uk/5599/1/EMA_REPORT.p df. Accessed 01.01.2015.

Flint, Nerilee and Johnson Bruce (2011). Towards fairer university assessment - recognising the concerns of students, London: Routledge.

Gibbs, Graham (2010). Using assessment to support student learning, Leeds: Leeds Met Press.

Gibbs, Graham and Simpson, Claire (2005). Conditions Under Which Assessment Supports Students' Learning, Learning and Teaching in Higher Education, Issue 1, Gloucester: University of Gloucestershire.

Higher Education Academy (2012). A Marked Improvement: transforming assessment in higher education, York: Higher Education Academy. http://www.heacademy.ac.uk/assets/documents/assessment/A_Mark ed_Improvement.pdf._Accessed 01.01.2015.

Higher Education Authority (2013). National Strategy for Higher Education: 2030

http://www.hea.ie/content/national-strategy-highereducation-2030. Accessed 01.01.2015.

Ibarra-Sáiz, Maria Soledad, and Rodríguez-Gómez, Gregorio (2010). Aproximación al discurso dominante sobre la evaluación del aprendizaje en la Universidad. An approach to the dominant discourse of learning assessment in higher education. Revista de educación, 351, pp. 385-407.

JISC (2007). Effective Practice with e-Assessment: An overview of technologies, policies and practice in further and higher education, http://www.jisc.ac.uk/publications/. Accessed 01.01.2015.

JISC (2010). Effective Assessment in a Digital Age: A guide to technology-enhanced assessment and feedback, http://www.jisc.ac.uk/publications/ Accessed 01.01.2015.

Kneale, Pauline E. (1997). The rise of the "strategic student": how can we adapt to cope?, in Armstrong, Steve, Thompson, Gail and Brown, Sally (eds), Facing up to Radical Changes in Universities and Colleges, London: Kogan Page.

McAleese, M. (2013). Report to the European Commission on Improving the quality of teaching and learning in Europe's higher education institutions.

McDowell, Liz (2012). Programme focussed assessment. Bradford: Bradford University http://www.pass.brad.ac.uk/short-guide.pdf. Accessed 01.01.2015.

McDowell, Liz and Brown, Sally (2001). Assessing students: cheating and plagiarism, The Higher Education Academy

http://jisctechdis.ac.uk/assets/Documents/resources/database/id430_cheating_and_plagiarism.pdf. Accessed 01.01.2015.

Newstead, Stephen E., Franklyn-Stokes, Arlene and Armistead, Penny (1996). Individual differences in student cheating, Journal of Educational Psychology, 88, pp. 229-241.

Nicol, David J. and Macfarlane-Dick, Debra (2006). Formative assessment and self-regulated learning: A model and seven principles of good feedback practice, Studies in Higher Education, Vol 31 (2), pp. 199-218.

Price, Margaret; Rust, Chris; O’Donovan, Berry; Handley, Karen and Bryant, Rebecca (2012). Assessment Literacy: 
the foundation for Improving student learning, Oxford: Oxford Centre for Staff and learning Development.

QAA UK (2013). Quality Code for Higher Education: Chapter B6: Assessment of students and recognition of prior learning.

http://www.qaa.ac.uk/publications/informationandguidance/pages/quality-code-b6.aspx.

Quesada-Serra, Victoria; Rodríguez Gómez, Gregorio, and Ibarra-Sáiz, Maria Soledad (2014). What are we missing? Spanish lecturers' perceptions of their assessment practices, Innovations in Education and Teaching International, pp. 1-12.

Race, Phil (2001). A Briefing on Self, Peer and Group Assessment, in LTSN Generic Centre Assessment Series No 9 York, UK: HEA/LTSN.

Rodríguez-Gómez Gregorio; Ibarra-Sáiz, Maria Soledad; and Jiménez, Eduardo (2013). Autoevaluación, evaluación entre iguales y coevaluación: conceptualización y práctica en las universidades españolas, Revista de investigación en educación, 2 (11), pp. 198-210

Sadler, D. Royce (1989). Formative assessment and the design of instructional systems, Instructional Science 18, pp. 119-144.

Sadler, D. Royce (2010). Beyond feedback: Developing student capability in complex appraisal. Assessment \& Evaluation in Higher Education, 35 (5), pp. 535-550.

Sambell, Kay (2013). Engaging Students Through Assessment, In Dunne, E. And Owen, D (eds) The Student Engagement Handbook: Practice in Higher Education, Bingley, UK: Emerald.

Sambell, Kay and Hubbard, Anntain (2004). The Role of Formative 'Low-stakes' Assessment in Supporting Non-traditional Students' Retention and Progression in Higher Education: Student Perspectives, Widening Participation and Lifelong Learning, 6 (2), pp. 25-36.

Sambell, Kay, McDowell, Liz and Brown, Sally (1997). "But is it fair?": An exploratory study of student perceptions of the consequential validity of assessment, Studies in Educational Evaluation, 23 (4), pp. 349-371.

Sambell, Kay, McDowell, Liz and Montgomery, Catherine (2012). Assessment for Learning in Higher Education Abingdon, Routledge.

Yorke, Mantz (1999). Leaving Early: Undergraduate Non-completion in Higher Education, Abingdon: Routledge.

I How to cite this article

Brown, Sally (2015). A review of contemporary trends in Higher Education assessment. @tic. revista d'innovació educativa. ( $\left.n^{\circ} 14\right)$. URL. Accessed, month/day/year. 